\title{
Tefsir Rivayetlerinin Güvenilirliklerini Belirlemek Amacıyla Herbert Berg Tarafından Geliştirilen "Uyum" (Consistency) Teorisi Üzerine1
}

\author{
MEHMET AKIF KOC \\ DR, ANKARA Ü. ILAHIYAT FAKÜLTESI \\ e-mail: koc@divinity.ankara.edu.tr
}

\begin{abstract}
On Berg's Theory of "Consistency" as a Criterion for the Reliability of Tafsir Narrations. There is an ongoing discussion among Muslim and non-Muslim scholars about the reliability of the hadith tradition and exegetical reports. Herber Berg's theory can be considered a recent contribution to this discussion. We consider that the theory of "consistency" Berg develops does not solve the problem of authenticity of these reports. There are various reason for this. First of all he fails to treat the problem in all its aspects. Secondly, his partial data he used in his theory is not compatible with his statistical conclusion about the exegetical reports. Finally, his usage of israd is inadequate.
\end{abstract}

key words

Authenticity, tafsir, narration, exegetical report, consistency.

Herbert Berg, Oryantalistik çalışmalarda önemli bir yer tutan "rivâyetlerin güvenilirliği" sorununu çözmek için bir yöntem geliştirmeyi hedeflemiştir." $\mathrm{O}$, öncelikle, kendisinden önce konu ile ilgilenen araşturmacılann katkılannı tahlil etmektedir. Bu noktada her bir araştırmacının kendisine özgü yaklaşımlan olmakla beraber genel bir tasnif imkanı da bulunmaktadır. Berg'e göre, "hadis rivâyetlerinin güvenilirlikler" bağlamında araştırma yapanlar genel olarak üçe aynlırlar:

1. Şüpheciler: $\mathrm{Bu}$ kısımda yer alan araştırmacilar isnad sisteminin kurgulandığını ve gerçeklere dayanmadığını düşündükleri için rivâyetlere de şüphe ile yaklaşırlar. Goldziher ile önemli bir çıkış yapan bu akım Stettter, Schacht, Wansbrough, Crone, Colder, Cook ve Rippin ile devam etmiștir. ${ }^{3}$

\footnotetext{
'Sakarya Üniversitesi'nin 11.12 Mayss 2002 tarihleri arasında gençekleştindiği "Oryantalizmi Yeniden Okumak" isimli sempozyumda sunulmuştur.

${ }^{2}$ Hertert Berg, The Derelopment of Exegesis in Early Islam, London: Curzon 2000.

3 a.g.e., s. 49-50, 93, 112.
} 
2. İsnad Sistemine Güven Duyanlar: Bu akımın temsilcileri isnad verilerinin referans kaynağı olarak görülmesinden yanadırlar. Bu bakımdan, onlann üzerinde yürüdükleri zemin Müslüman dünyaya yabancı değildir. Horovitz, Fück, Horst, Sezgin, Abbott, Birkeland, Stauth, Goldfeld, A'ẓamî, Wersteegh ve Motzki bu guruba girmektedir. ${ }^{4}$

3. Orta Yol Tezini Öne Çdkaranlar: Rabson, Junyboll, Rahman ve Coulson gibi ilim adamlan da yukanda zikri geçen iki kutup arasında yer almayı tercih etmişlerdir. ${ }^{5}$ Onlar konuya daha lıml bakmaya çalışmışlardır. ${ }^{6}$

Berg tefsir rivâyetlerinin güvenilirliği konusunda ise, kendisine gelinceye kadar ya "birinciler" ya da "ikinciler" gibi düşünüldüğünü söylemektedir. Aynca Berg, "şüpheci" Wansbrough ile "İsnad Sistemine Güven Duyan" Sezgin'i birbirine ters bu iki grubun temsilcisi olarak görmektedir?

\section{1. "Uyum" (Consistency) Teorisinin Tanitımı}

Berg'in, "uyum" (consistency) teorisi, istatistikî bir araştırmaya dayanır. $O$, arașturmasını, Taberînin (310/922) tefsirindeki 997 rivâyet üzerinden yürütmektedir. $\mathrm{Bu}$ rivâyetlerin seçiminde iki temel faktör rol oynamıştır. Birincisi onlarn, ibn 'Abbâs'tan (68/687) onun en meşhur öğrencileri Sa îd b. Cubeyr, (95/714) 'Ikrime (105/723) ve Mucâhid (103/721) tarafından nakledilmiş olmalandır. Diğeri ise bu 997 rivâyetin, Taberîye, tefsirinde en fazla ismi geçen şeyhleri aracılı̆̆yla ulaşmış olmasıdır. Berg'in teorisini tahlil etmeden önce, onun araştırmasının dizaynını gözler önüne seren şu tablolan vermek istiyoruz: ${ }^{8}$

Tablo IA

Ibn 'Abbās'in öğrencileri

$\begin{array}{lccccc} & \begin{array}{c}\text { 'Abdullāh } \\ \text { b. 'Abbās }\end{array} & \text { Sađìd b. Cubeyr } & \text { Ikrime } & \begin{array}{c}\text { Ibn Cubeyr ev } \\ \text { Clkrime }\end{array} & \begin{array}{c}\text { Mucãhid b } \\ \text { Cebr }\end{array} \\ \text { Basit îzah } & 317 & 134 & 82 & 41 & 60 \\ \text { Kissa } & 395 & 183 & 91 & 87 & 34 \\ \text { Merfô hadis } & 156 & 57 & 38 & 53 & 8 \\ \text { Müphemâtın îzâhı } & 448 & 176 & 113 & 108 & 51\end{array}$

\footnotetext{
4 a.g.e., s. 50,93, 119. Berg, özellikle Sezgin'i bu grubun en önemli teorisyeni olarak suk sık zikreder. Bkz. s.76, 83, 93, 113.

s a.g.e., s. 50

6 a.g.e., s. 26.

7 a.g.e., s. 112-113. Çünkü Bcrg'e göre, Wansbrough- Sezgin arasındaki mesafe, Goldziher-Sezgin arasındaki mesafeden çok daha fazladır. Bu sebeple de genel olarak hadis çalışmalanında Goldziher ve Sezgin arasında bir orta yol bulunabilirken; konu tefsir rivâyetleri olunca Wansbrough ve Sezgin arasında üçüncii bir yaklaşım mümkün olmamaktadır.Bkz. a.g.e., s.83, 93.

8 a.g.e., s.174, 176-178
} 
Tablo IA

Esbâb-ı nüzûl

Nesh

Kiyas

Takdir

Gramatik îzah

Kâmus bilgisi

Şiirle istişhad

Kiraat

Konu hârici

Belâğat inccicmesi

Tefsirle ilgisiz

Toplam hadis sayisı

\section{Tablo IB}

Basit îzah

Kissa

Merlo hadis

Mübhemátın îzahı

Esbab-ı nuzo

Nesh

Kıyas

Takdir

Gramatik îzsh

Kamus bilgisi

Siitk istişhad

Kırat

Konu hărici

Belağat incelemes!

Tefsirle Ilgisiz.
Ibn 'Abbäs' in öğrendleri

$\begin{array}{ccccc}146 & 39 & 32 & 68 & 7 \\ 14 & 8 & 4 & 0 & 2 \\ 3 & 3 & 0 & 0 & 0 \\ 4 & 2 & 1 & 1 & 0 \\ 4 & 2 & 1 & 0 & 1 \\ 34 & 13 & 16 & 0 & 5 \\ 9 & 1 & 4 & 1 & 3 \\ 18 & 11 & 4 & 0 & 3 \\ 52 & 30 & 14 & 3 & 5 \\ 0 & 0 & 0 & 0 & 0 \\ 10 & 7 & 1 & 0 & 2 \\ 997 & 429 & 264 & 146 & 128\end{array}$

\section{Ibn 'Abbās'ın öğrenciler}

\begin{tabular}{|c|c|c|c|c|}
\hline $\begin{array}{l}\text { 'Abdulláh } \\
\text { b. 'Abbàs }\end{array}$ & Sa'id b. Cubeyt & 'Ikrime & $\begin{array}{c}\text { Ibn Cubeyr ev } \\
\text { 'ikrime }\end{array}$ & Mucähid b. Cebr \\
\hline 31.8 & 31.3 & 31.1 & 28.1 & 469 \\
\hline 39.6 & 427 & 34.5 & 59.6 & 265 \\
\hline 157 & 133 & 14.4 & 363 & 6.3 \\
\hline 44.9 & 410 & 42.8 & 740 & 39.8 \\
\hline 147 & 9.1 & 12.1 & 46.6 & 5.5 \\
\hline 1.4 & 1.9 & 1.5 & 0.0 & 1.6 \\
\hline 0.3 & 0.7 & 0.0 & 0.0 & 0.0 \\
\hline 0.4 & 0.5 & 0.4 & 0.7 & 0.0 \\
\hline 0.4 & 0.5 & 0.4 & 0.0 & 0.8 \\
\hline 3.4 & 3.0 & 6.1 & 0.0 & 3.9 \\
\hline 0.9 & 0.2 & 1.5 & 0.7 & 2.3 \\
\hline 1.8 & 2.6 & 1.5 & 0.0 & 2.3 \\
\hline 5.2 & 7.0 & 5.3 & 2.1 & 3.9 \\
\hline 0.0 & 0.0 & 0.0 & 0.0 & 0.0 \\
\hline 1.0 & 1.6 & 0.4 & 0.0 & 1.6 \\
\hline
\end{tabular}


Tablo IIA:

\section{Taberīnin şeghter!}

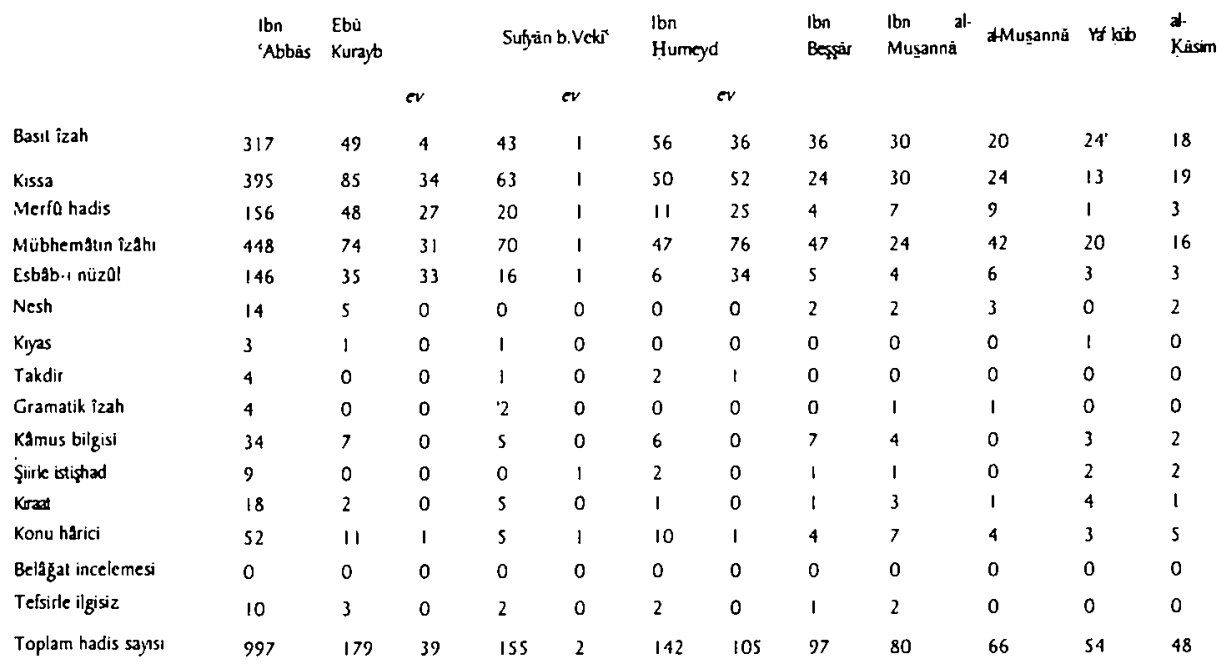

Tablo IIB:

\section{Taberi’nin şeytlert}

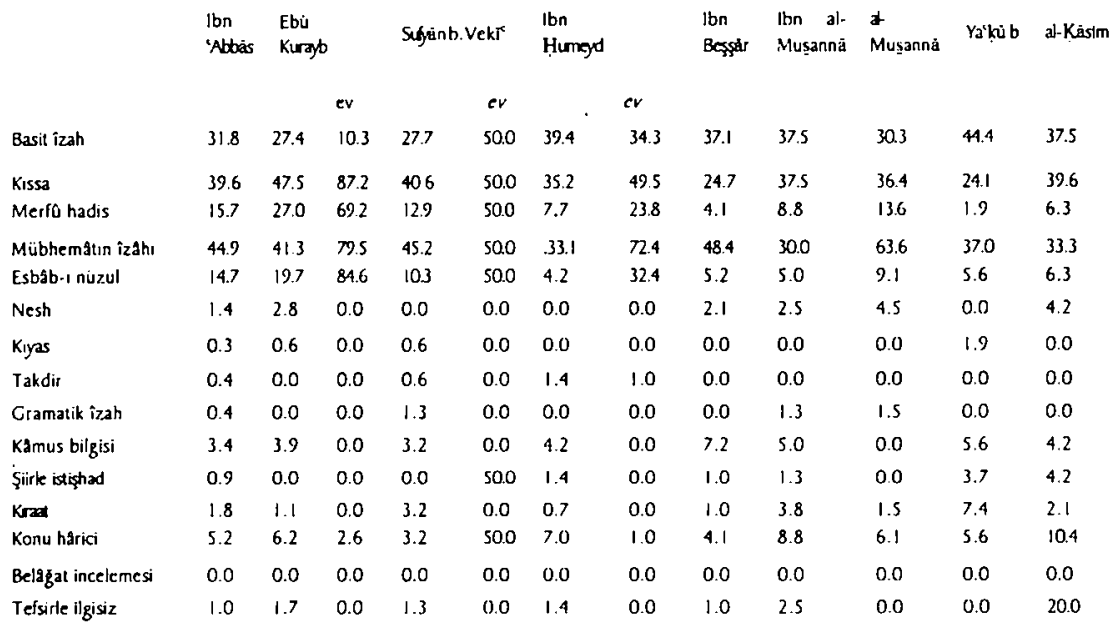


Berg, ilk olarak bu 997 rivâyeti, içerdiği konular bakımından 15 katagoriye ayırmaktadır.9 (Bkz. Tablo I A) Sonra bu rivâyetleri bir taraftan İbn 'Abbâs'a ve ayn ayn Sa'îd b. Cubeyr, 'İkrime ve Mucâhid'in ondan naklettikleri rivâyetlere göre; diğer taraftan da Țaben'nin bu rivâyetleri aldı̆̆ı şeyhlerine göre sınıflandırmaktadır. (Bkz. Tablo II A) Böylece Berg, 997 rivâyeti metinleri ve isnadlar bakımından 4 kademeli bir sınuflandırmaya tâbi tutmuş olmaktadır (Tefsir katagorileri, İbn 'Abbâs, İbn 'Abbâs'ın öğrencileri ve Țaber̂'nin şeyhleri). Teknik bir anlatımla, rivâyetlerin metinleri konulan açısından; isnadlan da zincirin en yukansındaki ve en aşağısındaki şahıslar (ravîler) bakımından guruplandırlmış olmaktadır.

Berg'e göre bu dağllum rivâyetlerin güvenilirliğini belirlerken önemli bir fikir verecektir. $O$, "uyum" (consistency) teorisini ortaya atarak rivâyetlerin güvenilirliklerini belirlemeye çalışmaktadır. Buna göre, sözgelimi incelenen 997 rivâyet içinde İbn 'Abbâs'tan sebeb-i nuzul konusunda gelen rivâyetlerin oran, (Tablo I B, \% 14.7) ayn ayn Sa îd b. Cubeyr'in, (\% 9.1) 'İkrime'nin, (\% 12.1) ve Mucâhid'in (\% 5.5) ondan naklettikleri rivâyetler içindeki sebeb-i nüzul rivâyetlerinin oranlanna yakın olmalıdır. ${ }^{10}$ Tabii ki, böyle bir karşılaştırma sözü geçen her bir katagori için de düşünülmelidir. Berg bununla da yetinmeyerek aynu karşlaş̧ırmay Taberînin şeyhleri arasında da uygulamaktadır."1 (Bkz. Tablo II A ve II B)

Berg'in çalışmasının ana çatısı bu şekilde özetlenebilir. $O$, araştırmasının sonucunda incelediği 997 rivâyet arasında kendince bir "uyumsuzluk" (inconsistency) tespit ederek bu rivâyetlerin kurguya dayalı bir temele dayandığını iddia etmiştir.12 Berg, ulaştığı sonuçlann sadece "şüpheci" araştırmacılan desteklediğini îtiraf etmekle beraber, ${ }^{13}$ araştırma metodunun konu ile ilgilenen bütün ilim adamlannca makbul bulunacağını öne sürmektedir. ${ }^{14}$ Böyle düşünmesinin en önemli sebebi, Berg'in -daha önce guruplar halinde zikrettiğimiz- konu ile ilgili araştırma yapan ilim adamlanından farklı olarak çok geçerli bir metod geliştirdiğine inanmasıdır. ${ }^{15}$

\footnotetext{
${ }^{9}$ Berg, Wansbrough'nın yaptı̆̆ 12'li katagorik ayırma 3 tane daha ilave ederek (basit izah, tefsirle ilgisiz ve konu hânci) 15 'li bir sıufflandırma elde etmiştir. Bkz. Wansbrough, Quranic Saudies, Oxford University 1977, s.121

10 Berg., s. 177.

"1 a.g.e., s. 118-120, 145-148, 173-174, 191.

12 a.g.e., 208, 215, 228.

13 a.g.e., s. 228.

14 a.g.e., s. 141, 228.

15 a.g.e., s. 119, 228.
} 


\section{II. "Uyum" (Consistency) Teorisinin Eleştirisi}

"Uyum" (Consistency) teorisine iki ayn eleştiri yöneltilebilir:

A. Teorinan daxandzğ istatistiğin dizaymna (design) yöndik elestivi: Berg'in araștırması incelendiğinde akla gelebilecek bazı sorular şunlardır. İbn Abbâs'in öğrencilerinin herhangi bir konuyla ilgili olarak Ibn Abbâs'tan naklettikleri rivâyetlerin miktarnda oransal "uyum" u gerektiren sebep nedir? Târihsel şartlar bir yana, konulara ilişkin kişisel eğilimler bile bu karşılaştırmayı anlamsız hale getirmez mi? Berg'in araştırmasının dizaynı, bunlan yeterince hesaba katmadığı için "hoca-talebe" ilişkisini gerçek dünyada tesâdüf edilemeyecek kadar mekanik bir zemine taşımış olmaz mı?

Berg, aslında bu sorulara kısmen cevap vermektedir.16 O, İbn 'Abbâs ve öğrencileri arasındaki rivâyet alı̧s-verişinde oranlamayı dikkate alan bir karşlaştırmanın yukanda dile getirmeye çalıştığımız aksaklıklan gündeme getirebileceğini varsayarak ikinci bir analiz yapmıstır. ${ }^{17} \mathrm{Bu}$ ikinci analize göre, aym rivâyetlerin Taberînin şeyhleri düzeyindeki râvîleri arasında da bir karşlaştırma yapulmış; böylece birinci karşılaştırmanın sonuçlanna ilişkin doğan aksaklıklar giderilmeye çalş̧ıııstır. Ancak şimdi zikredeceğimiz örnekten de açıkça anlaşılacağı üzere Berg, araştırmasınun dizaynunda önemli bir noktayı muğlak bırakmıştır: Taberînin 2. Bakara 35. ayetinin tefsiri sadedinde zikrettiği bir haberin isnadında şu şahıslar bulunmaktadır:

1. 'Abdullâh b. 'Abbâs (68/687)

2. Mucâhid b. Cebr (103/721)

3. Raculun min ehli'-'ilm

4. Muhammed b. 'İshâk (150/767)

5. Seleme b. el-Fadl (191/807)

6. İbn Humeyd (2487862)

7. $\operatorname{Taben}^{18}(310 / 922)$

Berg'in araştırmasında, İbn 'Abbâs'tan Mucâhid'e doğru gerçekleşen bilgi akışında Mucâhid'in ve diğer pek çok rivâyette ayn konumda yer alan Sa îd b. Cubeyr ve 'Ikrime'nin "seçici" olabilecekleri; bu sebeple de naklettikleri rivâyetlerin saylannda tabii bir farklılaşmanun doğacağ düşünülmüştür. Bu farkllaşmanın doğalliğ1 ya da kurgusalliğ1 da 6. râvî

\footnotetext{
16 a.g.e., s. 120.

17 a.g.e., s. 208.

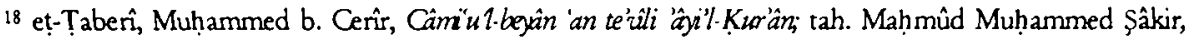
Daru'l-ma'ânif, Mısır-tarihsiz, I. 518.
} 
düzeyindeki bir başka karşılaştırmayla kontrol edilmiştir. Ancak Berg, 3. 4. ve 5. râvîlerin de "seçici" olabileceklerini hiç hesaba katmamıştır. Bu ömekte görüldüğü gibi, Berg'in araştırmasının dizaynındaki hata, sadece isnadlann en yukarısının ve en aşağısının dikkate alınması, zincirin diğer halkalarının ise göz ardı edilmesi sonucunda ortaya çıkmıstır. Böylece İbn 'Abbâs ile ögrencileri arasındaki rivâyet alış-verişinde muhtemel görülen öznellik (subjektivite) olgusu, İbn 'Abbâs'un öğrencileri ile onlann öğrencileri ya da daha sonrakilerle bu sonrakilerin öğrencileri arasında hiç hesâba katılmamıstır. Yukandaki örnekte gündeme getirilen bu eleştiriyi Berg'in tüm veri tabanına yöneltmek mümkündür.

Diğer taraftan isnadlarda yer alan bütün râvîlerin, tarihi şartlar gereği, şeyhlerinin naklettikleri haberlere farkh oranlarda ulaşabilecekleri kuvvetle muhtemeldir. Bu durumda onlann, şeytlerinden naklettikleri rivâyetlerin saylarunda doğal bir dengesizliğin ortaya çıkabileceğini varsaymak zorundayız. Anlaşlacağı üzere Berg'in, yukanda dile getirmeye çalıştığımız "seçicilik" öğesi yanında târihî konjonktüre bağı muhtemel değişkenlikleri yeterince dikkate almamasi, onun "uyum" ya da "uyumsuzluk" (consistency or inconsistency) tezini çok tartışlur hale getirmektedir. Böylece, bu teoriye bağh bir dizaynın özellikle böyle bir istatistikî araştırmada sağlıkl veriler sunamayacağ1 görülmektedir.

B. Teorinin kaynaklanna yöndik elestin: Berg, rivâyetlerin güvenilirliğini belirlemeye çalışırken "rical” malzemesini kullanamayacağını açıkça belirterek bunun sebeplerini şu şekilde özetlemiştir:

a. Rical malzemesi eksiktir.

b. Rical malzemesi şüphelidir. Aynca rical malzemesi böyle bir istatistikî çalışma için uygun değildir. ${ }^{19}$ Rical malzemesine bu derece ihtiyatl yaklaşan Berg'in, sadece Țaberî tefsirine güven duyabilmesi ilginçtir. Çünkü onun bu tefsirden yararlanışına da aynı tenkitler yöneltilebilir.

a. Taben̂́ tefsiri, bütün tefsir rivâyetlenini içermediği için eksiktir. Tefsir rivâyetlerini toplayan elimizdeki en önemli kaynak olmasına rağmen, Taberînin tefsiri bütün tefsir rivâyetlerini içermez. Sözgelimi Sa îd b. Cubeyr'den gelen rivâyetler konusunda Taberînin tefsiriyle İbn Ebî Ḥâtim'in (327/939) tefsiri farklı veriler sunmaktadır. Taberînin tefsirinde yüzden fazla tekerrür eden isnadlar içinde Sa îd b. Cubeyr kaynaklı bir isnad yer almaz.20

\footnotetext{
19 Berg, s. 136-137.

20 Horst, Heribert, Die Gereähsmärner in Korankammentar des TabaT, Ph.D. thesis, Bonn University, 1951, s. 9-22.
} 
Oysa ki, İbn Ebî Hâtim'in tefsirinde Sa î̀ b. Cubeyr kaynaklı bir isnad, 806 kere tekerrür etmiştir. ${ }^{21} \mathrm{Bu}$ isnad, İbn Ebî Ḥ̂atim'in tefsirinde meşhur 'Alî b. Ebî Ṭalhạa (143/760)-İbn 'Abbâs (68/687) isnâdından hemen sonra en fazla tekerrür eden ikinci isnad durumundadır.22 Görüldüğü gibi Ṭaberî ve İbn Ebî Hâtim hemen hemen aynı zamanda ve aym bölgeleri dolaşarak (nhhle) hemen hemen ayn tür bir eser derlemelerine rağmen farklı veriler sunabilmektedirler.

Hemen belirtelim ki, Taberî ya da Ibn Ebî Hâtim'in eserlerine dayanularak tefsir tarihine ilişkin genel yargılara varulabilir. Çinkü bunlar ansiklopedik eserlerdir. Ancak "uyum" (consistency) teorisinin dayandığ istatistik çalışmasının dizaynı, Taberî tefsirinin dışında kalan birkaç rivâyetin bile etkili olabileceği kadar hassas bir temele dayanmaktadır. Berg, araşturmasinda bu derece hassas bir dizayn oluşturduğu için, rical malzemesinden, bu malzemenin eksik olması sebebiyle uzak durarak tutarlı bir tercihte bulunmuştur. Ancak aynı eleştirinin kendi veri tabanı için de geçerli olduğunu görememiştir. Onun araştırmasına, bu açıdan yaklaşıldığında şu sonuç ortaya çıkar. Berg'in araştırması mâkul bir zemine oturmuş olsaydı bile, uygulama alanı ancak bütün tefsir rivâyetleri olması durumunda doğru sonuçlar verirdi. "Tefsir" in başlangıçtan beri geçirdiği evreleri inceleyen herkes görecektir $\mathrm{ki}$, bu gün Berg'in araştırmasının dizaynına uygun düşecek bir veri tabanına sahip değiliz.

b. Taberî tefsirindeki bütün rivâyetler sahih değildir. Ṭaberînin bile böyle bir iddiası yoktur. Çünkü bu tefsirdeki bazı rivâyetlerin güvenilirliği çok açık bir şekilde şüphelidir. Sözgelimi bundan önce "Araştırmanun dayandı̆̆ istatistiğin dizaynına (design) yönelik eleştin” konusunu işlerken zikrettiğimiz Ṭaber̂́nin İbn Humeyd'den (248/862) naklettiği rivâyetin, râvîlerinden üçüncüsü müphemdir. Bu durum, klasik hadis usûlü açısından rivâyetin güvenilirliğini olumsuz yönde etkiler. ${ }^{23} \mathrm{Bu}$ konuya bağhl olarak Berg'in rical malzemesinden uzak duruşunun bir sebebi de, bizzat Taberînin rical konusundaki görüşlerini öğrenebileceğimiz hacimli bir eserinden yoksun

${ }^{21}$ Sa'îd b. Cubeyr (95/714)- 'Atầ' b. Dînâr (126/744)- Abdullâh b. Lehîa (174/790)- Yahyầ b. 'Abdillâh b. Bukeyr (231/846). Ebû Zur'a (264/878)- Íbn Ebî Hâtim (327/939).

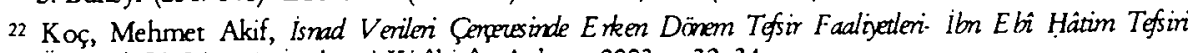
Ömeğgnde Bir L iteratïn Inclemes i Kitâbiyât, Ankara 2003, s. 32, 34.

23 Ibn Kesîr"in (774/1372) bu şahsı "Haccâc" olarak kaydetmesi de onun kimliğini ortaya

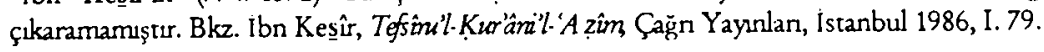


oluşumuzdur. ${ }^{24} \mathrm{Bu}$ durumda akla şu soru gelmektedir: Berg'in araştırması bakımından, Țaber̂́nin rical konusundaki görüşlerinden mahrum oluşumuz sorun teşkil ediyor $\mathrm{da}$, eserinde yer verdiğ $i$ rivâyetlerin güvenilirlĭgi hakkındaki kanaatlerini bilmeyişimiz neden problematik görünmüyor?

Taberînin, eserine kaydettiği çoğu rivâyetin güvenilirliği hakkundaki görüşleri bu gün hala merak konusudur. Zikrettiği bazı rivâyetlere eleştiri yöneltse de tefsirinden hareket edilerek, bu konuyu îtirâza mahal bırakmayacak bir netliğe kavuşturmak mümkün görünmemektedir. ${ }^{25}$ Ancak bu noktada Ṭaberînin "Târih"inin hemen başındaki çarpıcı ifâdeleri göz ardı edilmemelidir. $O$, burada ulaşabildiği tüm rivâyetleri derlediğini ve bunlann tamamının güvenilirliğini tartı̧̧maya açık tuttuğunu beyan etmektedir. ${ }^{26}$ Tefsirinde yer verdiği rivâyetlerle ilgili benzer bir kanaati olması da kuvvetle muhtemeldir. Çïnkü bu dönemde ulemanun "tefsir" ve "tarih" alanlann hemen hemen aynı katagori içinde değerlendirdiği bilinmektedir. ${ }^{27}$ Diğer taraftan Ṭaberînin, tefsirinde zikrettiği birbirleriyle çatı̧an pek çok rivâyet arasında rahatlıkla tercihte bulunabilmesi de tercih etmediği rivâyetlere karşı olumsuz bir tavır takınması şeklinde algılanabilir. ${ }^{28}$ Bundan başka Taberînin

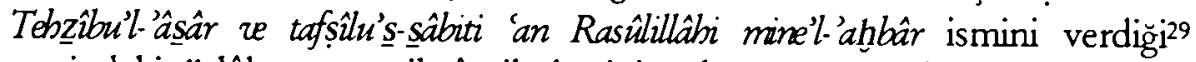
eserindeki üslûbu onun ilmî zihniyetini anlamamıza yardımcı olmaktadır. Ṭaberî bu eserinde önce kendince sahih olan rivâyetleri verir. Eserinin büyüik

${ }^{24}$ Berg, s. 137. TTaberìnin çağdaşı Ibn Ebî Ḥâtim'in tefsiriyle meşhur cerh ve tadil (kritik) kitabı arasında bir karşlaştırma yapmak mümkündür. Bu karşllaştırma sonucunda İbn Ebî Hâtim'in, tefsirinde, rical konusundaki yargılannın hilafına rivâyetler zikrettiği gözlenmektedir. ibn Ebî Ḥ̂tim'in sözkonusu bu iki eseri arasındaki uyumsuzluklann sebebini, ilk üç asırda yaşayan alimlerin "tefsir" ilmine bakş̧lannda aramak gerekir. Bkz. Koç, s. 135-156.

25 Ahmet Hamdi Savlu, Taberñnin eleştirenek vendiği bu rivâyetleri ve bu tefsirdeki diğer bazı zayf rivâyetleri tespit etmeye çalışmuşır. Bkz. Ahmet Hamdi Savlu, Müfessì Taberi we Tefsindeki Metodun basılmamış doktora tezi, Ankara Üniversitesi ilâhiyât Fakültesi, Ankara 1971, s. 76-92. Taberînin

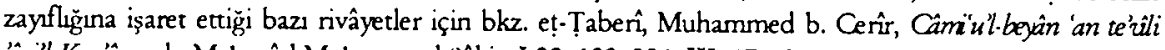
aàjil-Kư'ân' tah. Mạ̣mûd Muhammed Şâkir, I.32, 122, 354, III. 17, 474.

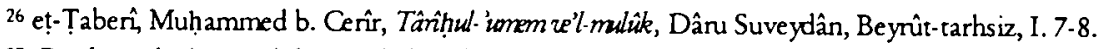

27 Bu konuda 'Aḷmed b. Hanbel'in (241/855) tefsir, tarih, mağâzî ve malâhim konulanu içeren kitaplardan kaçınmak gerektiği; bu kitaplann sağlam bir temele dayanmadĭ̆ı yolundaki meşhur görüşü

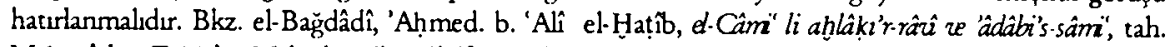
Mạ̣mûd et-Ṭaḥhân, Mcktebetu'l-ma'ânif, Ruyad 1983, II. 162.

28 Țaberî ve ṫbn Ebî Ḥâtim'in tefsirlerindeki en önemli farkllıklardan bir tanesi bu konuyla ilgilidir. Taberî çoğu âyetin tefsîrinde yer verdiği rivâyetler arasında rahatlkkla tercih yaparken, İbn Ebî Hâtim, tefsîrindeki rivâyetler arasında bir tercihte bulunmaz. Her iki müfessirin nvâyetleri derleme maksadı gütmelerine rağmen Taberinin "tercih" konusundaki bu farkl tutumunun, yukanda dile getirmeye

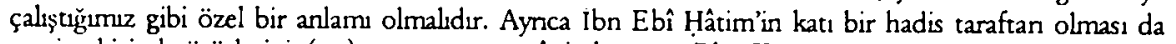
eserine kişisel görüşlerini (rey) yansıtmasına mâni olmuştur. Bkz. Koç, s.85.

${ }^{29}$ Maṭba'atu'l-medenî, tah. Maḥmûd Muḥammed Şâkir, Kâhire- tarihsiz. 
bölümünde ise kendisinin sahih gördüğ̈̈ bu rivâyetleri sahih görmeyenlerin delillerini aktarmaktadır. Taberînin kendinden önce görülmeyen bu üslûbu, onun "göreceli" (relativity) bir "sahihlik" anlayışna sahip olduğunu göstermektedir. Bu derece esnek bir ilmî yaklaşıma sahip olan Țabeñ̂nin, tefsirinde kaydettiği her bir rivâyeti sahih gördüğuniü düşünmek yanlsş olur. Sonuç olarak; Taberñnin, tefsirinde, bilinçli ya da bilinçsiz olarak sahih olmayan rivâyetleri zikretmesi, "uyum" (consistency) teorisinin geçerliğini olumsuz yönde etkiler. Çünkü bu teoride, teorinin dayandığı istatistiğin veri tabanındaki bütün rivâyetlerden sahihliklerine ya da illetlerine bakılmaksızın yararlanulmış ve onlar, birbirlerinin güvenilirliklerini kontrol etmek maksadıyla kullanulmışlardır. Bu sebeple onun, isnadlarda yer alan bilgilere güvenenler ya da en azından, bu bilgileri tamamen dı̧̧lamayanlar tarafından sorunlu bulunacağın söylemeliyiz.

Şimdi de "rivâyetlerin güvenilirlik sorunu" hakkında Berg"in dolaylı. olarak gündeme getirdiği bir konuyu incelemek istiyonuz: Eğer elimizdeki tefsir rivâyetleri büyük oranda kurgulanmı̧sa, kurgulayanlanı amaçlan doğrultusunda iş görmelidirler. Her şeyden önce bu rivâyetleri uyduranlar, onlan, vahiy ortamina en yakın kaynaklan referans göstererek uydurmus olmalidırlar. Bu çok tabï bir akıl yürütmedir. Ancak tefsir rivâyetlerini konu alan akademik çallşmalar, durumun böyle olmadığıu göstermektedir. Bu çalışmalara göre, tefsir rivâyetlerinin çoğunluğu $\mathrm{Hz}$. Peygamber'e ya da sahâbeye ulaşmaz. Onlar büyük oranda tâbün ve sonrasının ürünüdürler. ${ }^{30}$ Sözgelimi, yanya yakın bir bölümü elimizde olan İbn Ebî Hâtim'in tefsirindeki -ta'likler hariç- 16283 rivâyet içinde $\mathrm{Hz}$. Peygamber'in sözlü beyanlannın oranı \% 4'tür. Yine aynı tefsirin \% 22'si sahâbeye, \% 74'ü ise tâbün ve sonrasına âit rivâyetleri içermektedir. Bu tefsir daha aynntul bir analize tabi tutulduğunda şu sonuçlar ortaya çıkar: ibn Ebî Hâtim'in tefsirinin \% 18.5'i, bu tefsir içindeki sahâbe ile başlayan isnadlarnn \% 80'i İbn 'Abbâs'a dayanmaktadır. ${ }^{31}$ Taberînin tefsirinde de toplam rivâyetlerin \% 15'inde İbn 'Abbâs' 'n ismi yer almaktadır. ${ }^{32} \mathrm{Bu}$ veriler ışı̆ğnda Berg'in erken

\footnotetext{
${ }^{30}$ Horst, s. 66; Koç, s. 102-3; Birkeland, Harris, Od Muslim Opposition A gainst Interpretation of the Quran I Komission Hos Jacob Dybwad, Oslo, 1955, s. 36. Birkeland, bu sonucu sürpriz olarak nitelemiştir. Çünkï ona göre, başlangıçtan beri tasvip gören tefsir ilminin önde gelen simalan başta $\mathrm{Hz}$. Peygamber olmak üzere bir çok sahabî olmalyyd. Elimizdeki tefsir rivâyetlerinin çoğunluğu da onlara kadar ulaşmaliydi. Ancak Birkeland, " $\mathrm{Hz}$. Peygamber ve sahâbe dönemlerinde tefsir ne kadar gerekliydi?” Sorusunu hiç düşünmemiştir. Şüphesiz bu dönemlende çok gerekli olmayan tefsir, asıl îtibariyle tâbün döneminin bir ihtiyâcı olarak karşımıza çıkmaktadır.

$31 \mathrm{Koc}$, s. 117.

32 Berg, s. 142. Ibn 'Abbâs'ı tâbiîn müfessiri bir sahâbî olarak görmekte hiçbir sakınca yokđur. Cürrkü ondan gelen rivâyetler, daha ziyâde tâbün döneminde ortaya çıkan sorunlann çözümüyle ilgilidir.
} 
dönem tefsir rivâyetlerini incelemek için İbn 'Abbâs'ı tercih etmesini yerinde bir karar olarak görüyoruz. Ancak Berg'in ve bütün "şüpheciler"in cevaplaması gereken önemli bir soru bulunmaktadır. Eğer tefsir külliyâtı büyük oranda kurguya dayaliysa, bu rivâyetleri kurgulayanlar, onlann çoğunluğunu neden Hz. Peygamber'e ya da en azından sahâbeye kadar ulaştırmadilar? Bu şekilde uydurdukları rivâyetlerin güvenilirliklerini sağlama almak dururken, neden onların çoğunluğunu tâbïne ulaştırmakla yetindiler? Şüphesiz ki, bu durumun kurguladıklan tefsir külliyâtını daha az güvenilir hala getireceğini biliyorlard. ${ }^{33}$

Berg, araştırmasında bu sorular üzerinde çok yüzeysel olarak durur. ${ }^{34}$ Oysa ki, bu sorular sadece Berg"in değil, bütün "şüpheciler"in cevaplaması gereken temel sorulardır. Açıkça görüleceği üzere Berg'in ve "şüpheciler"in tefsir târihine bakş̧lanyla elimizdeki tefsir rivâyetlerinin realitesi çatışmaktadır.

Sahabe ve tabün neslinin ümmet nezdindeki otoritelerini öne sürerek yukanda zikri geçen sorulara cevap verilemez. Şimdi de Berg'in kayda değer bulduğu bu yanlıs yaklaşım üzerinde durmak istiyoruz $:^{35}$

Günümüzden bakıldı̆̆ında $\mathrm{Hz}$. Peygamber'in sözüne "merfû hadis", sahabe sözüne "mevkûf hadis", tabün sözüne de "maktû hadis" denmektedir. Erken dönemde ortaya çıkmış olmasalar bile bu kavramların etimolojik yapılan konumuza 1şık tutabilir. Sözü geçen kavramlann alt yapılan uzun bir tarihi süreç içinde şekillenmiştir. "Merfû" kavramı olumlu bir tanımlamay ifade ederken; "mevkûf" (kopuk), "maktû" (kesik) aslında iki olumsuz kavramdır. Çïnküi rivayet geleneğinde asıl olan, bir sözün $\mathrm{Hz}$. Peygamber'e ulaşmasıdır. Ona ulaşmayan rivayetler, gerçekte sorunlu görülen rivayetlerdir. Bu durum, sözü geçen üç hadis türünün kavramlaşmasında bile kendini göstermektedir. 'Ahmed b. Hanbel'in (241/855) tefsir rivayetlerini makbul görmeme sebeplerini incelerken bütün bunlar gözden

Yani Ibn 'Abbâs aslında yukanda yaptığımız analizlenin bir istisnası değildir. Bkz. Koç, s. 122, 128, 131-132.

33 'Azamî bu sonuyu daha geniş tutarak rivâyetlerin güvenilirliğini destekleyen çok önemli bir delil öne sürmektedir. Ona göre bu gün elimizde bulunan rivâyetlendeki teknik kusurlar, ('ilé) onlann otantikliğini de gösterir. Eğer rivâyetler uydurulmuş olsayd, kusursuz isnadlarla gelirlerdi. Bkz. el-

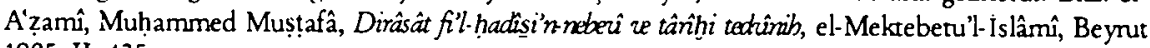
1985, II. 435.

34 Berg., s. 210.

35 Berg, s. 47, 210; Colder, Norman, Sadies in Earty Muslim Junispudence, Oxford, 1993, s. 236-237. 
kaçunlmamalıdı. ${ }^{36} \mathrm{O}$, çoğu tefsir rivayetinin tabïn neslinden geldiğini gördïğ̈i için böyle bir kanaate varmış olabilir.37

Aynca, sahabe ve tabünden gelen rivâyetlerin hicrî ilk üç asırda yaşayan müslümanlar nezdindeki bilgisel değerleri yeterince araştırlmuş değildir. Elimizdeki verilere göre, bu iki neslin doktriner otoritesinin hicrî III. yüzylda yaşayan İbn Ebî Hâtim ile gündeme geldiği söylenebilir. ${ }^{38}$ Onun rical kitabının hemen başında bu konular işlenmektedir. ${ }^{39}$ İbn Ebî Hâtim'in bu katagorik ayırımından sonra bile onun öğrencisi İbn 'Adiyy' in (365/976) aynı konudaki rahat tutumu ise dikkat çekmektedir. İbn 'Adiyy, eserinde, sahabenin birbirleri hakkındaki çok sert eleştirilerine yer vermeyi sakancalı

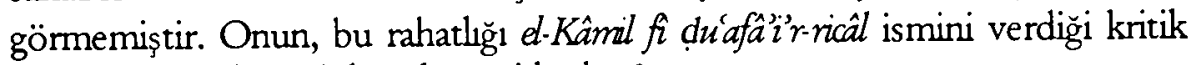
kitabında sergilemesi de çok manidardır. ${ }^{40}$

\section{Sonuç}

Berg"in geliştirdiği "consistency" (uyum) teorisi, tefsir rivâyetlerinin güvenilirlik sorununun çözümüne ş̧ık tutacak tatmin edici bir fikir verememiştir. Bunun en önemli sebebi, Berg'in, teorisini makul kulabilecek bir veri tabanına sahip olamayışıdır. Berg, "şüphecilerin" ve "isnad sistemine güven duyanlanı" şartlanmışlıklann eleştirerek onlann, rivâyetleri, kendi teorilerini doğrulamak gayesiyle kullandıklannı söylemektedir.41 Ancak Berg'in bu eleştirisi, cevaplanması gereken önemli bir soruyu akla getirmektedir: Berg de, elindeki veri tabanuna uygun bir teori geliştirmek yerine, onu kendi teorisi için uygun hâle getirmeye çallş̧mamış midır?

\footnotetext{
36 Bağdâdî, II. 162.
}

37 Ibn Teymiyye, (728/1328) 'Ahmed b. Hanbel'in (241/855) bu görüşüne açklltk getirmeye çalışmıstır.

Bkz. Meorứu fetâzâ, İşrâfu'r-n'âseti'l-'âmme li şu'ûn'l-ḥarameyni'ş-şerîfeyn, el-Mektebetu'l-

'Arabiyyeu's-Su' ûdiyye, tarihsiz, XIII. 346-347.

38 Junyboll, Islamda Illk Bügük Sijasi Fimenin Taribh, Oryantalistik Hadis Araştırmalan, çev. Mustafa Oztürk, Ankara Okulu Yaynlan, Ankara 2001 s. 42; Dickinson, Eerik Nael, The dectopment of earhy Mislim hadith critism The" Taqdima" of Ibn Ebî Hation er-Ràzĥ̀ Ph. D. thesis, Yale University 1992, s. 118,172 .

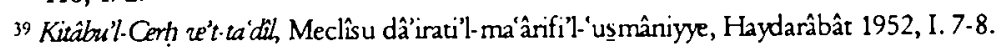

40 Ibn 'Adiyy, Ebû 'Ahmed, 'Abdullah el-Gurcânî, Dânu'l-Fikkr 1985, I. 61-63. Aynca bu konuda Zerkeşînin, (794/ 1392) Kitâbiyât tarafından çevirisi yayınlanan meşhur kitabı da kayda dȩ̧er niteliktedir. Bkz. el-Icâbe Hz. Á tienin Sababege Yöndtrigi Elestriler, hazırlayan Bünyamin Enul, Ankara 2000.

${ }^{41}$ Berg, s. 223. 